\title{
Homecoming (Mudik) and the Phenomenon of Social Brotherhood (Mangan Ora Mangan Asal Kumpul): A Question to The Importance of Togetherness During the Corona Pandemic
}

\author{
Diah Kristina $^{1}$, Rafika Nur Kusumawati ${ }^{2}$, Deniawan Tommy Chandra ${ }^{3}$, and Muhammad \\ Thoyibi $^{4}$ \\ \{diahkristina@staff.uns.ac.id ${ }^{1}$, Rafikasuntoro@gmail.com², bhayangkariwredha@gmail.com ${ }^{3}$, \\ Mth258@ums.ac.id $\left.{ }^{4}\right\}$ \\ PUI Javanologi, Universitas Sebelas Maret Surakarta, Indonesia ${ }^{123}$, Universitas Muhammadiyah \\ Surakarta ${ }^{4}$
}

\begin{abstract}
Homecoming ('Mudik' in Indonesian Language) has been a very crucial yet controversial issue in Indonesia especially among Javanese people living in diasporic areas. Contextually, mudik has to do with the belief in social brotherhood 'mangan ora mangan asal kumpul' (literally means despite in hunger the most important is to be together). Mudik normally reaches its peak during the 'Eid Mubarak in which Indonesian Muslims are celebrating their win over the hard struggle of fasting for a month. The study found that the old generation believes in the significance of homecoming for prestige and showing off financial and social gains. Meanwhile the millennials think that virtual connectivity and communication is sufficient. Therefore, this research is trying to solve the problem of physical distancing due to the covid-19 pandemic that makes physical homecoming impossible by providing digital interventions (Podcast and Video) which are expected to function as entertainment and education to raise awareness on physical distancing during the pandemic.
\end{abstract}

Keywords: homecoming, social brotherhood, video intervention, podcast, covid-19

\section{Introduction}

As cited by The Jakarta Post (2018), mudik or homecoming is the annual mass migration that occurs during the time of Idul Fitri in order to gather with family for celebrating the Religious Muslim Day in their hometown. Mudik has been a very crucial yet controversial issue in Indonesia especially among Javanese people living in diasporic areas. Contextually, mudik has also to do with the belief in social brotherhood mangan ora mangan asal kumpul (literally means despite in hunger the most important is to be together) [1]. Mudik normally reaches its peak during the Eid Mubarak in which Indonesian Muslims are celebrating their win over the hard struggle of fasting for a month.

According to the collected data from Badan Penelitian dan Pengembangan Perhubungan (Department of Transportation's Research and Development) in the last three years, the intensity of people doing mudik has surpassed over $15 \%$ of the total population in Indonesia. It is reported that there were 28,99 million leaving for their hometown in 2017. In 2018, the 
statistic had reached 18.79 million people. A year later, approximately 18.34 million were discovered by the authorized institution. Apparently, these people moved from their current place to other places, especially to their hometown, to visit their family during Idul Fitri. Furthermore, this tradition also provides the opportunity for the diasporic people to recharge their mind and spirit after working by gathering with their family.

Mudik (homecoming) is culturally bound to the mindset of Indonesian people, especially Javanese [2], [3], [4]. While the phenomenon of mangan ora mangan asal kumpul (social brotherhood) has equally been very strong among the Javanese as a form of sociological and psychological glue to foster their kinship in the feeling of brotherhood. This philosophy underlines the meaning that the togetherness needs to be prioritized over personal matters. Therefore, people can be aware of themselves properly as social beings that will focus more on the social relationship and put the personal interests aside [5].

Nevertheless, there has been a misleading in the perception of "mangan ora mangan asal kumpul" in which literally understood as having the nuance of egocentrism in the context of COVID-19 pandemic related to the physical distancing to stop the outbreak of the CoronaVirus. Philosophically, the saying has the message of a strong brotherhood, mutual collaboration and understanding as members of the Javanese communities. However, since there is a dramatic decrease of psychological and social awareness on the Javanese norms and values, the concept of mangan ora mangan asal kumpul is literally perceived as an effort of opposing to the government regulation for enforcing the health protocol, especially on the aspect of physical distancing and avoiding being in the crowd.

Taking an example from the field, we have noticed that there was an incident in which the diasporic family members were insisting to return to their hometown by hiding inside the towing-cart which then resulted them getting arrested on the police raid as reported by Kompas.com 2020. This incident happened due to the mudik ban regulation set by the Indonesian Ministry of Transportation (Ministry Regulation No. 25/2020 signed by acting minister Luhut Pandjaitan on April 23) to prevent the COVID-19 from spreading in one region to another region.

However, since this activity has been culturally acknowledged by majority of Indonesian people, they manage to keep their persistence to be able to do mudik whatever the way is even though it may be against the rule. Additionally, as stated by Detik.com (2020), there was another incident reported by the journalist about people who are doing illegal travelling by driving an overloading car with over 15 passengers. The police then gave a penalty by marking/labelling their identity, including the car, and telling them to turn their way back. Thus, by observing several cases presented above, it can be assumed that most of Indonesian people will maintain their conservative mindset especially by celebrating their Idul Fitri around their family in their hometown so that they are doing mudik whatever the cost is.

The study is believed to have a novelty in terms of going home during the COVID-19 pandemic and the new perspective on looking at the concept of mangan ora mangan asal kumpul. Previous studies related to homecoming or mudik were done by some researchers [6], [7] which was literally related with the concept of mangan ora mangan asal kumpul. In order to elaborate perceptions on mudik (homecoming) and the phenomenon of mangan ora mangan asal kumpul, these are formulated in the following research questions:

a. What are the responses of the Indonesian people who usually return to their hometown regarding mudik during the COVID-19 Pandemic at the time of Eid Fitr?

b. How far is the social belief of mangan ora mangan asal kumpul influences Indonesian people, especially Javanese, in responding to the tradition of mudik during COVID-19 Pandemic. 


\section{Research Methods}

This research aims at exploring the perception of the Javanese concerning home-coming (mudik) and the phenomenon of social brotherhood (mangan ora mangan asal kumpul) during the Corona Pandemic elicited from 500 respondents using google survey. Respondents were those belonging to $20-30 ; 30$ - 40; and 40 years up groupings, most of them were private sector workers and students. They were mostly Senior High School and University graduates, originally from Central Java and Jogyakarta. Banten and DIY are the most popular diasporic towns. Length of stay ranges from $5-15$ years.

Descriptive Analysis using SPSS 23 is employed to describe the frequency and distribution of homecoming and social brotherhood phenomena as well as the reliability and validity. The reliability test showed that the Cronbach Alpha number was 0.832 and the obtained $r$ value was 0.71-0.81 ( $\mathrm{r}$ table: 0.138 ). The instrument has a good level of reliability with valid question items. Furthermore, the instrument was made using the google form and questionnaire which was distributed via https://bit.ly/KuesionerBRINPandemiCovid-19. The questionnaire was opened for two weeks in the month of May 2020. The respondents who had participated to fill out the online questionnaire were 507 people in total.

Data analysis was carried out after obtaining data from respondents through three stages. The data was obtained from google form which was stored in .xls then analysed using SPSS 23. The first stage of the data analysis was using descriptive analysis in the form of frequencies to analyze the demographic data of the respondents. Data analysis is displayed in a form of pie charts to ease the readers to see the demographic pattern of the respondents. The next stage was descriptive analysis in a form of frequencies and percentages that were done to analyze the respondents' perceptions toward the concept of homecoming for them. In order to provide a more balanced result, the statistical data analysis was also crosschecked with results of interviews with Javanese community leaders taped and formatted in a features documentary video. In the last stage, the researcher will discuss and interpret the results of the obtained data analysis.

The data also collected by conducting an in-depth interview towards several chosen personages, two of them were; Kanjeng Gusti Pangeran Haryo (KGPH) Puger from Keraton Kasunanan Surakarta and Dr. Drajat Tri Kartono, M. Si. as a Senior Advisor to Rector for Academic Affairs Universitas Sebelas Maret Surakarta. This in-depth interview is undertaken directly with the interviewees by asking some open questions in which the informants provided responses in their own words. The purpose of handling this interview is to obtain the qualitative data in order to support the preliminary data taken from the online survey.

\section{Results and Discussion}

After conducting the research by holding an online survey with 507 respondents at the age of 20 years to over than 40 years old, the result shows that $46.6 \%$ of the respondents agreed that homecoming or mudik is an activity which must be done every year especially at the time of Eid Mubarak is shown in the following charts (3.1 - 3.6). 


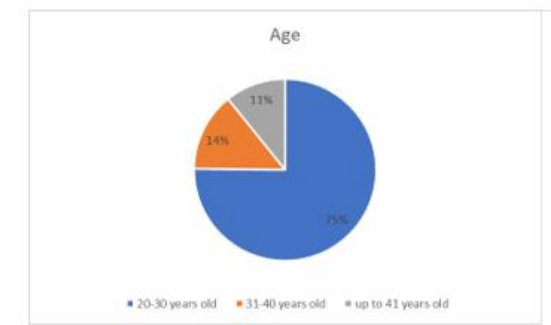

Chart 3.1

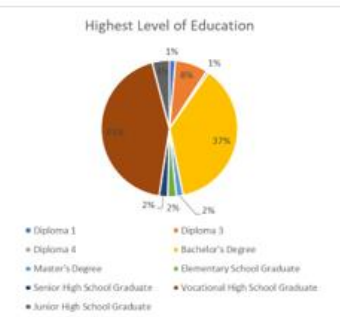

Chart 3.2
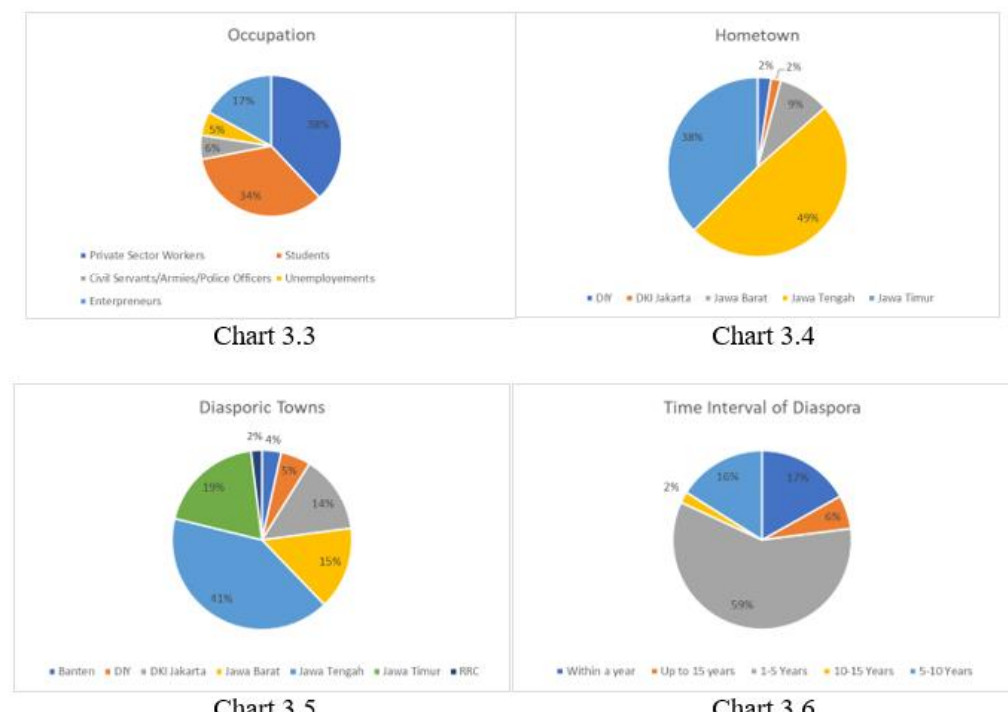

Chart 3.5

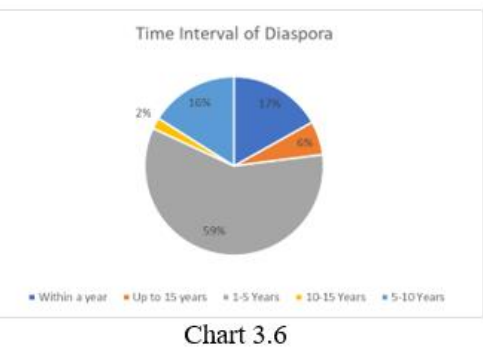

This phenomenon of homecoming is caused by the perspective that mudik is a form of tradition that has been rooted in Indonesian society, especially in Javanese culture. The majority of respondents also agreed with the idea that going home was able to strengthen social relationships and provide an opportunity for people to forgive each other in the Religious Muslim Day according to Islamic teachings.

COVID-19 Pandemic brings a great impact towards Indonesian society, especially Javanese people. This community holds various cultural backgrounds and signatures that become the basic aspect in dealing with the stressor in which the mindset of mangan ora mangan asal kumpul and mudik tradition laid a strong ground for their behaviour. Apparently, this tradition is in contrast with the physical distancing regulation to stop the spread and outbreak of Corona Virus. In reality, however, people are insisting to travel across the regions to meet with their family.

This phenomenon encourages the researcher in conducting a survey towards the same respondents to find their perceptions on how the social belief of mangan ora mangan asal kumpul influences Indonesian people, especially Javanese, in responding to the tradition of mudik during COVID-19 Pandemic. Based on the online survey, approximately $42.5 \%$ of respondents remain to take the Javanese cultural principle mangan ora mangan asal kumpul as a consideration in responding to the Eid homecoming activities. This philosophical view itself is sparked on the basis of a sense of kinship and togetherness with their closest relatives. 
Apparently, this moment of gathering will be considered an invaluable incidence for those who live far away from their hometowns. Besides doing a thorough exploration on mudik phenomenon, the researchers also conduct a study on a behavioural intervention that aims to provide perspectives on limiting mudik rate. This behavioural intervention is in the form of a video constructed to intervene the urge of going home especially during the Eid mubarak as reported in the previous research. The media intervention used was made based on setting up characteristics of the media intervention, defining the types of the media intervention, creating the media intervention, validating the media intervention, adapting the media intervention, and lastly, introducing the media intervention to the society.

The research resulted in the making of media intervention in the form of a video having the purpose to change people's behaviour, feeling, and ways of thinking. Video intervention entitled Tak Mudik Tanda Sayang (Resisting Homecoming as a Form of Caring) is produced by the researchers to disguise the impression of dictating people. For that reason, the intention of changing behavior, feeling, and ways of thinking is done indirectly. Since the video intervention Tak Mudik Tanda Sayang was created for millennials, another type of video intervention was made for those who belong to the 40 years age group, namely documentary features in the form of interviews with Javanese culture stakeholders (representative of the Karaton/Palace, academician, and community leader).

Dr. Drajat Tri Kartono, M. Si., Senior Advisor to Rector for Academic Affairs Universitas Sebelas Maret stated the followings:

“Contohnya di Solo, ada pendekatan "Jogo Tonggo” atau "Pager Mangkok” dimana masyarakat akan tetap mempraktekkan solidaritas mekanik dalam kasus adanya warga yang terjangkit COVID-19 dengan saling membantu satu sama lain sehingga bisa menciptakan social security nett yang mencerminkan arti "Kumpul” itu sendiri." said Dr. Drajat which means that Solo has given an example of implementing the terms "Kumpul"

The philosophy of social solidarity "Jogo Tonggo" or "Pager Mangkok" refers to the willingness of the Javanese people to keep the social collaboration in which the citizens will help each other to establish a social security network during the Covid-19 pandemic that reflects the terms "Kumpul" (togetherness) itself. Additionally, Kanjeng Gusti Pangeran Haryo (KGPH) Puger from Keraton Kasunanan Surakarta highlights the concept of "Mangan Ora Mangan Asal Kumpul" in relation with physical distancing by recommending "Banyu Mili" (doing activity in turns and in sequence). Interviews conducted on November 4, 112020.

With regard to the video intervention, the researcher also conducted an online survey to some students and lecturers by asking them to assess the video in terms of its adequacy to the taste of the millennials. The result shows that $60 \%$ informants do agree that the content of the video supports the idea of physical distancing enforced by the government. However, some suggestions related to the technique of video production raises the issue of dullness. Therefore, some modifications are made to meet the expectation. Results of the survey on video intervention suggest that it relatively succeeds to change people's behaviour, feeling, and ways of thinking.

Findings of the study support the fact that "Mudik" has been an arena for showing off the success of the diasporic people financially as stated by Fuad (2011), because mudik contains an existential value that most people want to share with their hometown folks. This is motivated by the psychological belief that the diasporic people need to be perceived as a well-respected individual who can give a contribution to his family well-being. 
Subsequently, Mudik can be used as a means of strengthening relationships with the family and relatives as reported by Tandywijaya (2020) and Fuad (2011). Through the tradition of maintaining relationship and togetherness in the Eid Fitr moment, the diasporic people will be able to find their meaning of life better.

Furthermore, mudik can be used as a medium of mind rejuvenation and spiritual conscience for the diasporic people. Fuad (2011) asserted that mudik has a transformative value to individuals having the homecoming identified through the energized spirit, high motivation gained after returning from their hometown. This experience may encourage them to work with a much stronger motivation and enthusiasm. For that reason, mudik brings beneficial impacts for the diasporic people in uplifting their spirit and making their life improved as supported by results of this study.

\section{Conclusion}

This paper has shown that the old generation of the Javanese believes in the significance of home-coming for prestige and showing off financial and social gains. Besides, mudik is also a means to strengthen social relationships and also to recharge mind and spiritual conscience. Mudik and the phenomenon of mangan ora mangan asal kumpul are significant Javanese values together with their perspective on social brotherhood which is culturally bound to their lives.

However, the COVID-19 Pandemic has made Mudik impossible to be done at the time of Eid Mubarak that leads to stress for those living away from their hometown. On the other hand, some informants who are not able to do mudik believe that maintaining relationships with others can be done virtually due to the advancement of technology. Many believe that living in this digital era makes it effective and efficient to communicate. First because it is safe in terms of health and secondly as it is more economical.

\section{References}

[1] Achmad, S. W. (2018). Etika Jawa: Pedoman Luhur dan Prinsip Hidup Orang Jawa. Yogyakarta: Arashka.

[2] Arribathi, A. H., \& Aini, Q. (2018). Mudik dalam Perspektif Budaya dan Agama (Kajian Realistis Perilaku Sumber Daya Manusia). Cyberpreneurship Innovative and Creative Exact and Social Science. 4(1). 45-52. https://www.neliti.com/publications/299607/mudik-dalam-perspektif-budayadan-agama-kajian-realistis-perilaku-sumber-daya-ma

[3] Irianto, A. M. (2012). Mudik dan Keretakan Budaya. Humanika. 15(9). 1-10. https://doi.org/10.14710/humanika.15.9.

[4] Yulianto, V. I. (2012). Is the Past Another Country? A Case Study of Rural-Urban Affinity on Mudik Lebaran in Central Jawa. Journal of Indonesian Social Sciences and Humanities. 49-66. https://doi.org/10.14203/jissh.v4i0.118

[5] Tandywijaya. E. (2020). "Mangan Ora Mangan, Sing Penting Kumpul" (Makan Tidak Makan yang Penting Kumpul) Tinjauan Filosofis "Aku dan Liyan" dalam Gagasan Togetherness Para Filsuf Barat. Jurnal Ilmu Budaya. 8(2). 198-207. https://doi.org/10.34050/jib.v8i2.10984

[6] Lubis, A. R., Fachrizal, F., Lubis, M. (2017). The Effect of Social Media to Cultural Homecoming Tradition of Computer Students in Medan. ScienceDirect. 124. 423-428. https://doi.org/10.1016/j.procs.2017.12.173

[7] Prasojo, A. P. S., Aini, Y. N., Kusumaningrum, D. (2020). Potensi Pola Aliran Mudik Pada Masa Pandemi COVID-19. Jurnal Kependudukan Indonesia. 21-26. https://doi.org/10.14203/jki.v0i0.579 
[8] Baskoro, H. (2010, September 13). Lebaran: "Mangan Ora Mangan Kumpul”? Retrieved from Harian Kompas: https://haryadibaskorokompas.wordpress.com/2010/09/16/lebaran-mangan-ora-m angankumpul/

[9] Bell, Paul. A., Fisher., Jeffrey. D,. Baum, Andrew., Greene Thomas E. (1990) Environmental Psychology. Third Edition. Fort Worth: Holt Rineheart and Winston.

[10] Ilham, A. (2014, Oktober 17). Makna Rumah. Retrieved from Republika: https://republika.co.id/berita/ndkfa3/makna-rumah

[11] Iskandar, Z. (2012). Psikologi Lingkungan: Teori dan Konsep. Bandung: PT. Refika Editama.

[12] Mulder, N. (1985). Pribadi dan masyarakat di Jawa. Yogyakarta: Sinar Harapan.

[13] Sarafino, E. P., \& Smith, T. W. (2012). Health Psychology: Biopsychosocial Interactions. United States: John Wiley \& Sons. Yusuf, N. (2020, Maret 24).

[14] Yusuf, N. (2020, Maret 24). Lockdown Dalam Perspektif Budaya Mangan Ora Mangan Kumpul. Retrieved from Jatim Times: https://jatimtimes.com/baca/211395/20200324/074100/lockdowndalam-perspekt if-budaya-mangan-ora-mangan-kumpul 